\title{
A Framework for Quantitative Assessment of Impacts Related to Energy and Mineral Resource Development
}

\author{
Seth S. Haines, ${ }^{1,19}$ Jay E. Diffendorfer, ${ }^{2}$ Laurie Balistrieri, ${ }^{3}$ Byron Berger, ${ }^{4}$ Troy Cook, ${ }^{1,17}$ \\ Don DeAngelis, ${ }^{5}$ Holly Doremus, ${ }^{6}$ Donald L. Gautier, ${ }^{7}$ Tanya Gallegos, ${ }^{1}$ Margot Gerritsen, ${ }^{8}$ \\ Elisabeth Graffy, ${ }^{9}$ Sarah Hawkins, ${ }^{1}$ Kathleen M. Johnson, ${ }^{10}$ Jordan Macknick, ${ }^{11}$ \\ Peter McMahon, ${ }^{12}$ Tim Modde, ${ }^{13}$ Brenda Pierce, ${ }^{10}$ John H. Schuenemeyer, ${ }^{14}$ \\ Darius Semmens, ${ }^{2}$ Benjamin Simon, ${ }^{15}$ Jason Taylor, ${ }^{16,18}$ and Katie Walton-Day ${ }^{12}$
}

Received 22 February 2013; accepted 20 April 2013

Published online: 15 May 2013

Natural resource planning at all scales demands methods for assessing the impacts of resource development and use, and in particular it requires standardized methods that yield robust and unbiased results. Building from existing probabilistic methods for assessing the volumes of energy and mineral resources, we provide an algorithm for consistent, reproducible, quantitative assessment of resource development impacts. The approach combines probabilistic input data with Monte Carlo statistical methods to determine probabilistic outputs that convey the uncertainties inherent in the data. For example, one can utilize our algorithm to combine data from a natural gas resource assessment with maps of sage grouse leks and piñon-juniper woodlands in the same area to estimate possible future habitat impacts due to possible future gas development. As another example: one could combine geochemical data and maps of lynx habitat with data from a mineral deposit assessment in the same area to determine possible future mining impacts on water resources and lynx habitat. The approach can be applied to a broad range of positive and negative resource development impacts, such as water quantity or quality, economic benefits, or air quality, limited only by the availability of necessary input data and quantified relationships among geologic resources, development alternatives, and impacts. The framework enables quantitative evaluation of the trade-offs inherent in resource management decision-making, including cumulative impacts, to address societal concerns and policy aspects of resource development.

KEY WORDS: Energy resources, mineral resources, impact assessment, integrated assessment, environmental.

${ }^{1}$ Central Energy Resources Science Center, U.S. Geological Survey, Denver CO 80225, USA.

${ }^{2}$ Geosciences and Environmental Change Science Center, U.S. Geological Survey, Denver CO 80225, USA.

${ }^{3}$ U.S. Geological Survey, Seattle WA 98195, USA.

${ }^{4}$ Crustal Geophysics and Geochemistry Science Center, U.S. Geological Survey, Denver CO 80225, USA.

${ }^{5}$ Department of Biology, University of Miami, Miami FL, USA.

${ }^{6}$ Berkeley Law, University of California, Berkeley CA, USA.

${ }^{7}$ U.S. Geological Survey, 345 Middlefield Road, Menlo Park CA, USA.

${ }^{8}$ Department of Energy Resources Engineering, Stanford University, Stanford CA, USA.

${ }^{9}$ Consortium for Science, Policy, and Outcomes, Arizona State University, Tempe AZ, USA.

${ }^{10}$ U.S. Geological Survey, 12201 Sunrise Valley Drive, Reston VA 20192, USA.
${ }^{11}$ National Renewable Energy Lab, Golden CO, USA.

${ }^{12}$ Colorado Water Science Center, U.S. Geological Survey, Denver CO 80225, USA.

${ }^{13}$ U.S. Fish and Wildlife Service, Denver CO, USA.

${ }^{14}$ Southwest Statistical Consulting, LLC, Cortez CO, USA.

${ }^{15}$ Office of Policy Analysis, U.S. Department of the Interior, Washington DC, USA.

${ }^{16}$ National Operations Center, Bureau of Land Management, Denver CO, USA.

${ }^{17}$ Present address: Energy Information Administration, U.S. Department of Energy, Washington DC, USA.

${ }^{18}$ Present address: Cape Cod National Seashore, National Park Service, Wellfleet MA, USA.

${ }^{19}$ To whom correspondence should be addressed; e-mail: shaines@usgs.gov 


\section{INTRODUCTION}

Many critical questions facing society involve natural resource availability, development, and use. Availability assessments of energy and mineral resources (e.g., Charpentier and Cook 2010; Singer and Menzie 2010) help decision makers, the private sector, and the general public to make informed decisions regarding these resources, but traditionally these studies do not consider external costs and benefits (e.g., positive or negative impacts on ecologic, hydrologic, and socioeconomic systems) of resource development and use. Similarly, assessments of water and ecological/biological systems generally lack quantitative linkage to energy and mineral resource development. Single-resource assessments are tremendously important, but development decisions increasingly require additional information to support analysis of the trade-offs among diverse natural resources. This information includes direct effects of resource development (e.g., habitat lost or jobs created), resource co-dependencies (e.g., water required for mining), and resource availability conflicts (e.g., subsurface coal deposits made inaccessible by co-located gas well pads or protected areas). This type of assessment fits into the broad category of study that is often described as "integrated assessments." In this manuscript, we focus specifically on linking energy (mainly petroleum) and mineral (in particular, nonfuel minerals) resources with the potential impacts of their development.

A number of efforts have been made to link assessments of related resources; they include varying degrees of quantitative integration across the disciplines and employ a variety of integration methods. Mulder and Hagens (2008) consider returns on investment for energy technologies that include impacts on natural and human systems, while Snyder and Kaiser (2009) and Thórhallsdóttir (2007) compare costs and benefits of particular development strategies. Other approaches focus on the environmental (Copeland et al. 2009; Okey and Kuzemchak 2009), human-health (National Research Council 2009), or water consumption (Nicot and Scalon 2012) implications of energy development and use. Studies can produce site-specific, geographically detailed information (Noble 2008; Fargione et al. 2012), or they can produce national-scale information (International Atomic Energy Agency 2005). None of these studies, however, establish a broadly applicable methodology that is based on robust assessments of the specific energy or mineral resource being considered and quantitative assessments of the impacts of interest.

To address this need, we (the authors) met in a workshop setting for three meetings of approximately 3 days each, spread over 16 months. In addition, we held weekly telephone calls and web meetings during the final 8 months of the effort. Our assembled group includes diverse technical expertise (including geology, geophysics, geochemistry, hydrogeology, ecology, social science, economics, law, statistics, and more), employment (government, academia, and private industry), and experience. Due to its composition, the group initially struggled with communication and managing diverse expectations about scope and objectives, but we found common language and vision and were able to accomplish what we set out to do. This manuscript presents the central findings of our work.

We propose a framework for quantitative assessment of natural resource development impacts (positive and negative), which is based on the linkage of established energy and mineral resource assessment methods with data and models that describe the biologic, water, social/economic, and other effects of resource development. We link energy and mineral resources that are in the ground with the potential surface impacts of their development and provide a means for comparing different development options. The framework is intended to provide consistent, reproducible, unbiased results to address a broad spectrum of resource management questions at a range of spatial scales (with primary initial focus on geologic-basin-scale assessment of geologically occurring resources). The framework can accommodate any desired level of linkage across disciplines, including both economic and non-economic valuation, while maintaining the standardization of methods and results that is essential for widespread utility. The objective is to enable betterinformed resource management decision-making by quantifying the inherent trade-offs.

In this article, we provide background information on resource assessments in general, and on existing methods for quantitative assessment of energy and mineral resources. We then describe the impact assessment framework and aspects of its implementation. Finally, we provide two conceptual examples, one involving the impacts of energy resource development and one involving the impacts of mineral resource development. 


\section{BUILDING BLOCKS FOR ASSESSING RESOURCE DEVELOPMENT IMPACTS}

Resource development impact studies begin with a question/problem, or a set of questions/ problems, that motivates the work and defines bounds for the study. This motivation could be a broad resource availability question or a specific location-based concern, and the information may be desired by decision makers in the public or private sectors, and/or by other individuals. For example, federal policy analysts, technology companies, and environmental organizations might wish to contrast the environmental cost of the United States filling its need for copper in the coming decades with the technological and economic benefits of this copper entering the marketplace. As another example, recreationalists, petroleum companies, and state and federal land managers might wish to better understand the potential impact on sage grouse and local job creation in western Colorado if the untapped natural gas is produced in that area.

Resource development impact studies also begin with the multi-disciplinary data required to answer these questions, potentially including geological information relevant to energy or mineral resource occurrence, biological information regarding vegetation types and species habitat, and water information regarding the quantity and quality of surface and groundwater. Much of this information may be available as the outputs of separate disciplinary resource assessments such as quantitative water, biological, energy or mineral resource assessments. Nearly all data, measurements, and assessments are estimates; the inherent uncertainty can be, but is not always, quantified. A robust approach for describing the uncertainty is the use of probability density functions (PDFs) to describe the possible values for a given measurement or estimate, rather than incorrectly assuming a single value; this approach is scientifically sound and it is effective for communicating uncertainty.

Schmoker (2005) and Charpentier and Cook (2010) describe methods to estimate the quantity of undiscovered "continuous" petroleum resources that can be recovered with existing technology. Continuous resources (e.g., petroleum shale systems and coalbed gas) are aerially large accumulations of oil and/or gas, generally within low-permeability rock; in a separate category are conventional resources, which are discrete accumulations of petroleum held in place by geologic traps and the buoyancy of petroleum relative to water (Schmoker 2005). The methods are peer-reviewed (AAPG Committee on Resource Evaluation 1999) and widely applied. Assessment of continuous petroleum resources begins with the definition of assessment units (AUs), which are the smallest explicit spatial subdivisions of a geologic formation that can be made based on available geologic and geophysical information. For each AU several variables are defined (as PDFs), including estimates of the drainage area of each well (termed the "cell size"), the number of untested cells that contain petroleum, and the estimated ultimate recovery of petroleum per cell (Fig. 1a). These PDFs are estimated based on geologic, geophysical, geochemical, and petroleum production data from the local area, or from analogous areas. Any existing wells within the AU represent cells that are "tested;" the assessment estimates the quantity of undiscovered petroleum in the untested cells. The input data are combined in a Monte Carlo simulation (Crovelli 2005) that determines the total undiscovered technically recoverable petroleum in the AU, as a PDF (Fig. 1a). The resource quantity estimate informs a suite of regional, national, and global planning questions including possible economic analysis. The resource quantity estimate, along with the input data, is also suitable for incorporation with diverse datasets as described below.

Singer and Menzie (2010) and Singer (1993) describe an assessment method (Fig. 1b) for mineral resources. The method is based on the determination of three assessment parts: (1) maps of permissive tracts (PTs) wherein the resource has a probability of existing that is greater than 1:100,000, (2) grade-and-tonnage models that describe mineral content and deposit size, and (3) the estimated number of undiscovered deposits in the PT. PTs are delineated based on geologic and geophysical data using descriptive deposit models, and can be seen as somewhat analogous to the AUs of petroleum assessments. Grade-and-tonnage models consist of compiled data for well-studied deposits of a given deposit type. The estimated number of undiscovered deposits is combined with the grade-and-tonnage models in a Monte Carlo approach (Root et al. 1992), yielding PDF estimates of the quantity of each assessed resource in the PT (Fig. 1b). These estimates are useful on their own, and for economic and other analyses to support decision making (e.g., Spanski 1992; Gunther 1992). Furthermore, the inputs to the Monte Carlo approach and the wealth 
(a) Assessment elements for continuous petroleum resources

Inputs

Output
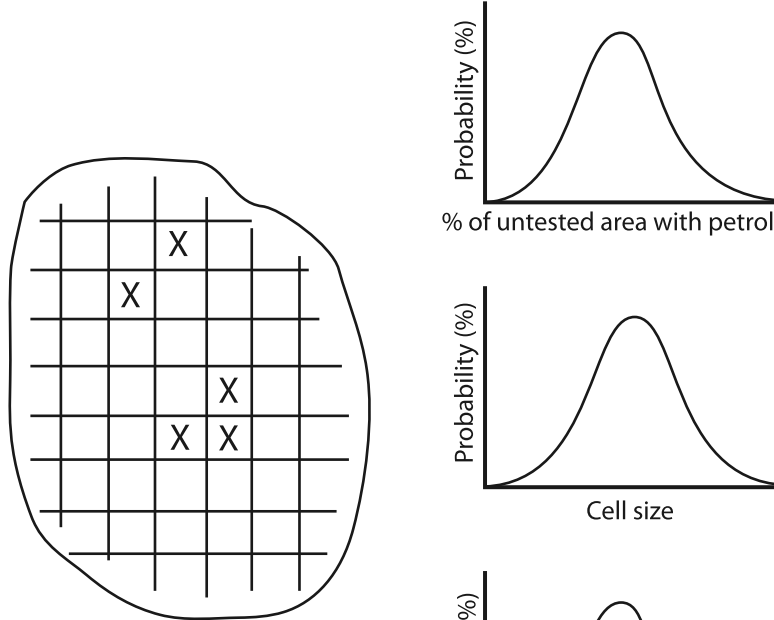

$\%$ of untested area with petroleum
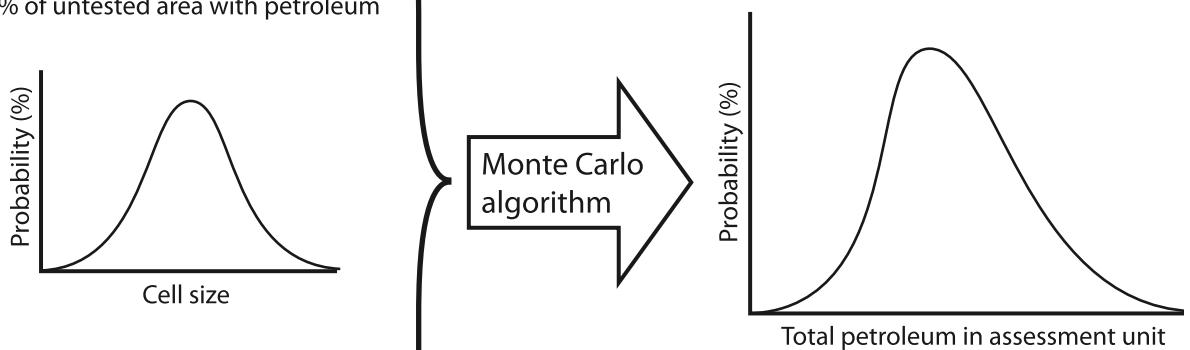

Assessment unit (map area), shown with cell boundaries and tested cells (X's)

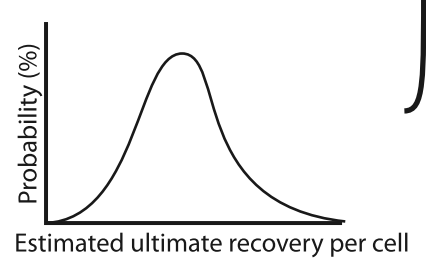

(b) Assessment elements for non-fuel mineral resources

Inputs

Output

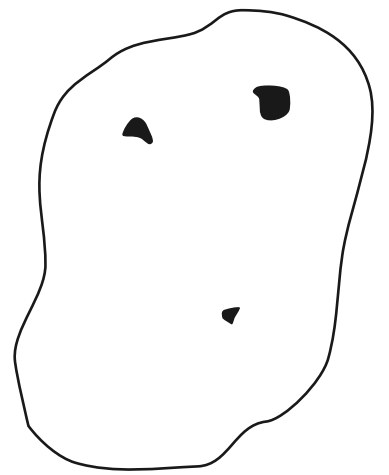

Permissive tract (map area) including known deposits
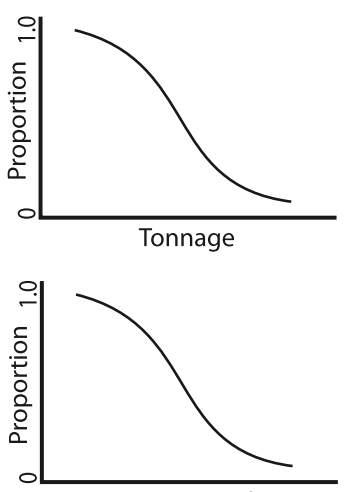

Average grade

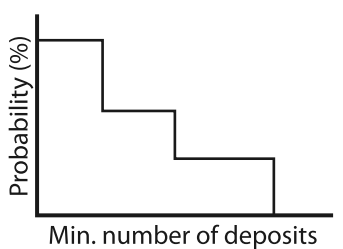

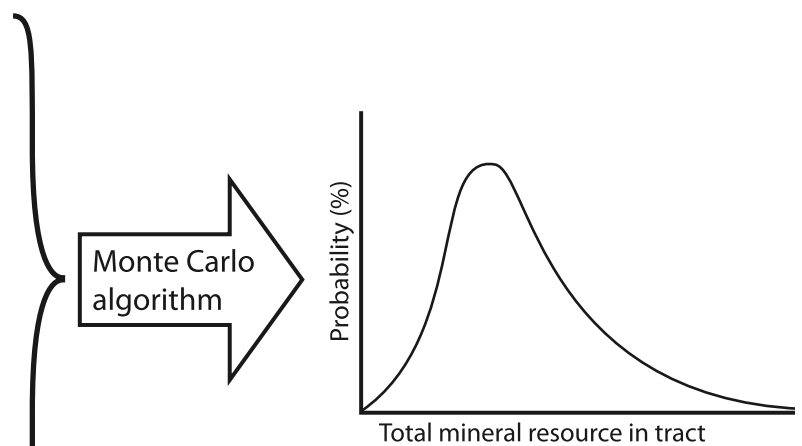

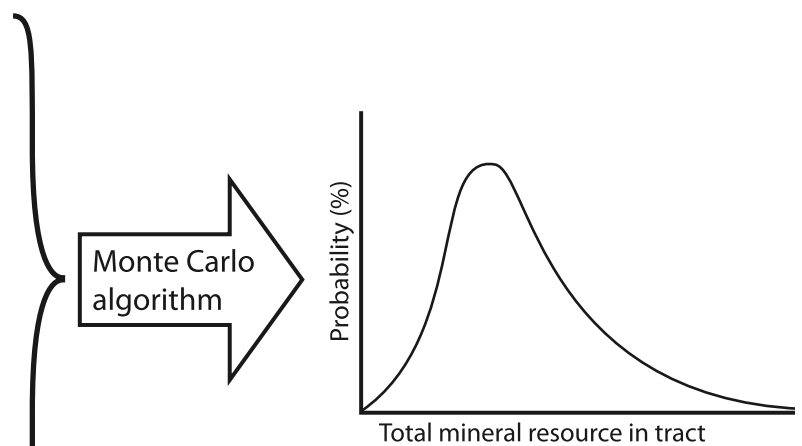

Figure 1. Fundamental elements of USGS assessment methodologies for (a) continuous petroleum resources and (b) mineral resources.

of geologic information that is assembled for the assessment are suitable for integration with other diverse datasets as described below.
Meaningful synthesis of varied but geographically related data requires comparative approaches and metrics that are suitable to the question and 
resources considered. The field of economics provides a suite of tools, but most environmental goods and services (in contrast to energy and mineral resources) are not bought and sold in markets and thus have no established monetary values. Environmental and resource economists (e.g., Unsworth and Bishop 1994; Champ et al. 2003; Farber et al. 2006) have developed an array of quantitative and qualitative techniques to estimate the benefits for what are characterized as "non market" environmental goods and services such as the benefits provided by the existence of a particular outdoor recreation area or the water filtration and storage provided by a wetland. For cases where benefits can be monetized, cost-benefit analysis provides an approach for comparing alternate scenarios, while habitat equivalency analysis (e.g., Hufschmidt et al. 1983; Dunford et al. 2004) and resource equivalency analysis (Zafonte and Hampton 2007) provide approaches for non-monetary linkage between resources and habitat.

\section{ASSESSMENT TERMINOLOGY}

A broad continuum exists within the realm of resource development impact assessments, extending from tightly focused assessments of a single resource to complex assessments of a suite of resources and their interrelations, potentially including a large degree of stakeholder involvement. Our group defined three categories, or levels, of assessment for our own use, and to provide structure and clarity for analysis and communication with stakeholders in future assessments (Table 1). We stress that these levels are not a series to be followed in order, nor are they mutually exclusive or tied to spatial scale. The choice of which level of assessment is appropriate in any given situation would be based on policy and societal requirements for the study and the availability of relevant data and funding.

A Level 1 assessment (Table 1) is the assembly of data from different disciplines as appropriate to the question being addressed, potentially including relevant and available mineral and energy assessment results and associated mapping and other datasets, as well as water quantity and quality data, habitat mapping and other ecological/biological data, and any desired human/social data such as population information. The assembled data could include calculated indices that describe ecological health or vulnerability (e.g., habitat suitability maps) along with basic spatial analysis to identify areas of geographic overlap between resources of interest, but no quantitative integration or modeling of development impacts. At minimum, a Level 1 assessment provides a starting point for a more detailed study. In some cases, it will provide all of the desired information, such as a study of resource availability and habitat overlap. Level 1 studies can take many forms, including the studies described by Okey and Kuzemchak (2009), Randall et al. (2010), Latysh and Bristol (2011), and Allen and Kauffman (2012).

A Level 2 assessment (Table 1) represents a consistent and repeatable integration of data across disciplines, employing standardized approaches (many of these approaches may not currently exist, at least not in a standardized form). These analyses are intended to provide quantitative estimates of potential development impacts (e.g., habitat loss or job creation) and interdependencies between resources (e.g., water required for petroleum development). Level 2 assessments could be conducted in response to a wide range of questions, including national-scale resource availability studies

Table 1. Assessment Nomenclature

\begin{tabular}{llll}
\hline & Level 1 & Level 2 & Level 3 \\
\hline Compiled available data & Yes & Yes & Yes \\
$\begin{array}{l}\text { Additional data acquisition } \\
\text { Stakeholder involvement }\end{array}$ & $\begin{array}{l}\text { None, or only during } \\
\text { project inception } \\
\text { and results } \\
\text { dissemination }\end{array}$ & $\begin{array}{c}\text { Possibly } \\
\text { Generally just project } \\
\text { inception and results } \\
\text { dissemination }\end{array}$ & $\begin{array}{c}\text { Yes } \\
\text { Throughout project: } \\
\text { inception, execution, } \\
\text { results dissemination }\end{array}$ \\
$\begin{array}{l}\text { Quantitative cross-disciplinary } \\
\text { integration }\end{array}$ & None & Standardized methods & Customized methods \\
& & & for the case in \\
& & & question
\end{tabular}


and local-scale resource-conflict evaluation. The main distinction from Level 1 assessments is that Level 2 assessments employ quantitative approaches to link processes across varied disciplines (e.g., cause-and-effect relationships, etc.). The key characteristic of Level 2 assessments is that these approaches are standardized and robust. Due to this characteristic, stakeholder involvement is generally only necessary for the conception of projects and the presentation of results. The primary objective of this manuscript is to introduce a framework for conducting Level 2 assessments in a wide range of applications.

A Level 3 assessment (Table 1) is a fully customized study involving new data collection and analyses, and often the development of analysis methods specific to the question being addressed. Stakeholder involvement is as extensive as warranted or desired, from project conception through data analysis and results dissemination. These assessments can include highly detailed process models that describe interactions and feedbacks between system components and drivers of change. Level 3 assessments could also include full life-cycle analysis of resources or materials to more fully quantify the impacts due to extraction, use, and disposal or reuse. Due to its complexity, a Level 3 assessment is undertaken to meet a specific need or in response to a request for highly specialized information. Many existing resource impact assessment studies (e.g., Mihalasky et al. 2006; Thórhallsdóttir 2007; National Research Council 2009) fit in the Level 3 category because they represent highly detailed one-time studies using site- or study-specific evaluation methods.

\section{QUANTIFYING RESOURCE DEVELOPMENT IMPACTS}

A key component of Level 2 and 3 assessments is the quantitative linking of resource development with impacts, and a key aspect of Level 2 studies is that quantification methods be standardized. To address this need, we present an approach for quantifying the positive and negative impacts of energy and mineral resource development based on established assessment approaches for the energy or mineral resource in question, building from ideas presented by Hawkins et al. (2012). The algorithm (Fig. 2) combines input PDFs with the Monte Carlo method, in which we randomly simulate a large number (e.g., 10,000) of possible future scenarios to determine PDFs that describe the range of possible impacts. Within each simulation there are two steps, detailed in the following paragraphs: (1) assigning the quantity and geographic location of energy or mineral resource based on information in the respective resource assessment, and (2) quantifying the possible impacts of developing the simulated energy or mineral resource based on input impactrelated data.

We simulate the quantity of energy or mineral resource in each Monte Carlo iteration based directly on the information in the associated energy/mineral assessment. For continuous petroleum, we use the PDFs describing the cell size and the percentage of the untested AU area that has potential to add to reserves to calculate a PDF that identifies the number of untested cells in the AU that contain petroleum. For minerals, we use PDFs of the number of undiscovered deposits in a PT and of the grade and tonnage of those deposits to simulate the number and size of undiscovered deposits in the PT. We can filter these mineral deposits with an economic algorithm (e.g., Robinson and Menzie 2012) if desired to eliminate those that are uneconomic. We next simulate the specific locations of the petroleum-containing cells or the mineral deposits, in most cases by randomly distributing the resource across the AU or PT. In some cases, additional information may be available, for example geologic mapping that constrains the likely location of minable mineral deposits within the PT, or the assumed likelihood that infill drilling of established oil/gas fields will bring AU well density to what is predicted by the cell size, but it must be borne in mind that any such constraints are uncertain. Regardless, the result is a map illustrating one possible scenario of the quantity and location of the energy/mineral resource. Any particular map from a given iteration is surely incorrect, but a sufficiently large number of iterations will produce a large number of maps that cumulatively represent the range of possibilities indicated by the input data.

We assign surface infrastructure to each energy or mineral location as necessary to evaluate the particular impact in question. Each petroleum-containing cell can be seen as representing one surface extraction point that requires a well pad and associated infrastructure, or we can incorporate assumptions regarding multiple wells per well pad. The exact location of the infrastructure within the cell can be 
Inputs
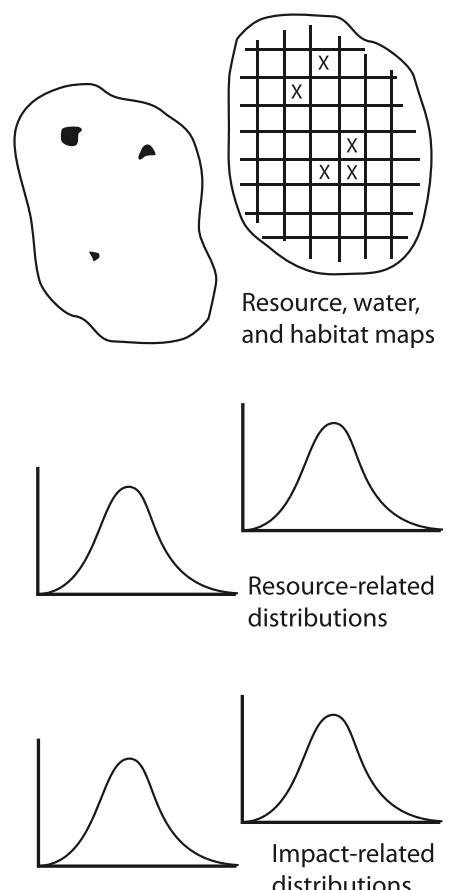
distributions
Process

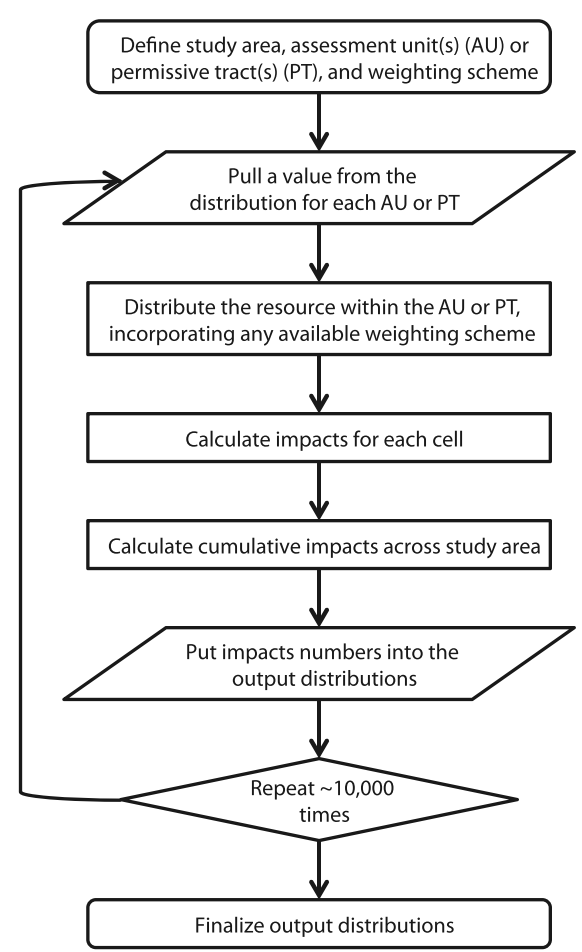

Outputs

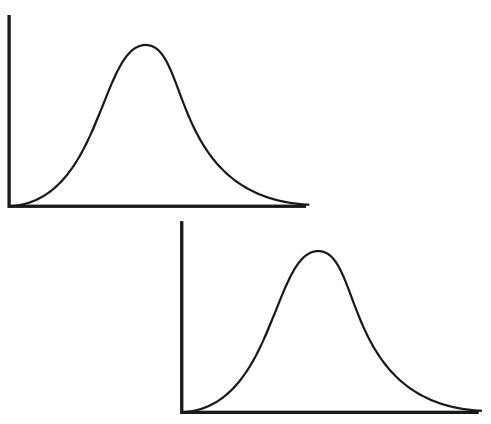

Distributions of potential impact

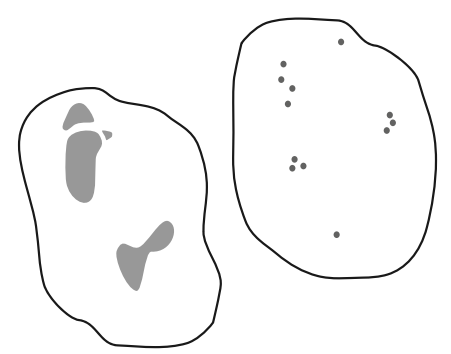

Optional, depending on context: Maps showing spatial aspects of potential impact

Figure 2. Fundamental elements of the proposed development impact quantification tool include the input PDFs and maps, the Monte Carlo process, and the output distributions. Maps showing spatial aspects of the impacts may also be available, depending on the assessment objectives and input data.

important for some assessments, and for better accuracy the simulation can take into account realistic constraints on well pad and road siting, such as topography and proximity to the existing road network. We can estimate the mine footprint for each undiscovered mineral deposit based on the deposit size and on data for the specific deposit type. The footprint simulation can incorporate the existing road network via a spatially explicit system identifying the most efficient means of extending a road to the site and its associated disturbance footprint, including any desired logistical or environmental restrictions. The complexity of the incorporated development infrastructure model (well or mine layout, design, and operations) can be tailored to the particular impact being assessed. For example, quantifying habitat loss or increased sediment load entering a stream requires assumptions regarding the exact well or mine location along with road construction and other engineering choices. On the other hand, quantifying water used for gas well drilling or jobs created to support copper mine operations does not require such specific information.
We calculate the impacts of interest for each Monte Carlo iteration using the simulated locations of wells or mines, the actual locations of existing water, biological, or other resources (as relevant), and the quantified relationships that predict the impacts due to the energy or mineral resource development (Fig. 2). The data required will depend on the impacts being assessed. Examples of possible input data include per-well or per-mine PDFs of: water use or production (e.g., gallons of water per well/mine), surface disturbance (e.g., acres of land per well/mine), job creation (e.g., number of jobs per well/mine) and air quality disturbance (e.g., pollutant release per well/mine). These PDFs would be estimated based on data from local or analogous areas and those for mines will be dependent on deposit size. Other types of development impact relationships could also be included, such as the quantified relation between well pad presence and behavior (mortality or avoidance) of a threatened species (e.g., Walker et al. 2007). The input data will also include whatever fundamental data are required to make use of the development impact relationships, 
such as habitat maps (for assessing possible habitat impacts), water quantity/quality data (for assessing possible water impacts), and human population estimates (for assessing human-related impacts). Impacts are calculated for each extractive resource development location (well or mine), and cumulative impacts are calculated across the study area; this result provides one possible scenario for impacts associated with the extractive resource(s) of interest. By repeating this process through a sufficiently large number of iterations, the scenarios will span the likely possibilities, and PDFs developed from the combined output of all the iterations will provide a quantified, probabilistic estimate of potential impacts. Output data can also include maps showing the probability of impacts within the AU or PT; these maps will primarily be useful in cases where the simulation of the resource locations and/or the infrastructure is based on reasonable constraints and realistic modeling.

As described, the Monte Carlo impact assessment algorithm is centered on a particular AU or PT. For studies that involve a larger number of AUs or PTs, we can calculate total impacts by assessing all of the AUs or PTs simultaneously; these cumulative impacts can be correctly determined only within a single Monte Carlo framework. When appropriate, the algorithm can provide maps representing the summation or compilation of the individual simulations produced in each Monte Carlo iteration, with specific details dependent on the question being addressed. These maps will be most relevant in studies involving cumulative impacts for several AUs/PTs, or for cases where trusted spatial constraint information is available to guide the simulation of where the resource falls within the AU/PT or of where the development infrastructure exists within a petroleum-containing cell. For any desired application of this assessment algorithm, consideration must be given to the availability of the necessary input data, and/or to the acquisition of the data needed to provide outputs with acceptable uncertainty. Many pressing questions may require considerable augmentation of existing datasets.

\section{CONCEPTUAL EXAMPLES OF QUANTIFYING DEVELOPMENT IMPACT}

We illustrate the proposed assessment framework with two conceptual examples for which the necessary data and quantified development impact relationships are available. For each example the assembled input data constitute a Level 1 study in our three-level system. The studies themselves would fit into Level 2 because the analyses are envisioned as being standardized, and some of the more complex variations described later would constitute Level 3 studies due to the need for highly complex data and analyses.

\section{Piceance Basin Natural Gas, Piñon-Juniper Forest, and Sage Grouse Leks}

The Uinta-Piceance Basin is a depositional sedimentary basin in western Colorado and eastern Utah (Fig. 3) assessed by the USGS for undiscovered oil and gas resources (Johnson and Roberts 2003). We focus on the Piceance Basin Continuous $\mathrm{AU}$, which was estimated to contain a quantity of gas described by a PDF that indicates a $95 \%$ chance of at least 1.90 trillion cubic feet (TCF), a $50 \%$ chance of at least $2.96 \mathrm{TCF}$ and a $5 \%$ chance of at least 4.59 TCF. The AU consists mainly of the Mesaverde Group, a geologic unit that is composed predominantly of shale. Production of petroleum from such formations represents an increasingly large fraction of the US energy profile, and it generally involves the drilling of a considerable number of wells (thousands) spread over a large region. The proposed Monte Carlo impact quantification approach (Fig. 4) requires the cell size and the percent of the area of the AU that is expected to contain technically recoverable resource, both provided by Johnson and Roberts (2003).

The Uinta-Piceance Basin also includes piñonjuniper (PJ) woodlands (Fig. 4) that provide habitat for a variety of wildlife including 24 bird species, 5 insect species, 9 mammal species, and 6 reptile species of conservation concern in the state of Colorado (Colorado Division of Wildlife 2006). If we wish to quantify the area of PJ woodland potentially affected by petroleum development, the inputs necessary for the Monte Carlo approach include a map of the areal extent of PJ woodland and a quantified relationship between gas development and habitat health. A more comprehensive study could consider all infrastructure and transportation requirements, but for the purposes of this conceptual example, we simply assume that any well pad that is placed in an area of PJ woodland will destroy the overlapping area of habitat. This 


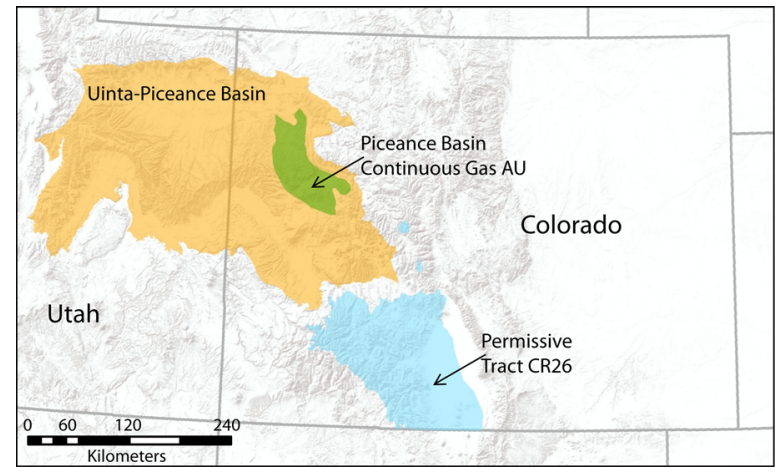

Figure 3. Study areas for the two conceptual assessment examples: the Uinta-Piceance Basin including the Piceance Continuous Gas Assessment Unit (AU), and the San Juan volcanic zone (broadly, the mountains of southwest Colorado) and minerals permissive tract CR26.

Inputs

Outputs
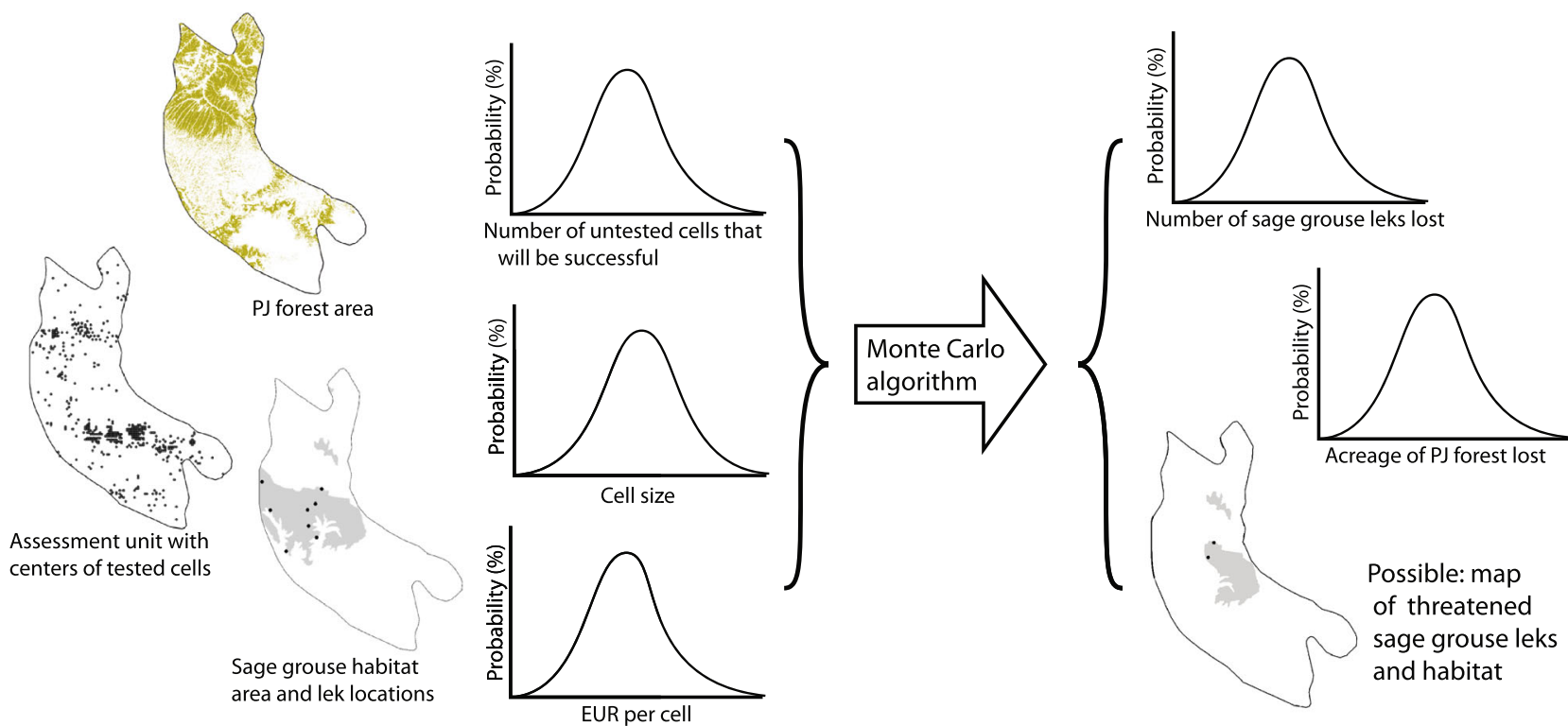

Figure 4. Inputs and outputs for the Uinta-Piceance Basin conceptual example. The assessment incorporates relevant inputs from existing USGS assessment of continuous gas along with maps of the "tested" cell locations, the piñion-juniper (PJ) woodlands, and sage grouse leks to determine the possible acreage of lost PJ woodland and the possible number of lost sage grouse leks corresponding with possible gas development.

provides a quantitative relationship between habitat acreage and gas development.

In addition, the Uinta-Piceance Basin is also home to greater sage grouse, currently a candidate ("warranted but precluded") for listing under the Endangered Species Act (Fish and Wildlife Service 2010). Sage grouse leks are established strutting grounds where males congregate and mating occurs (Fig. 4); they, and adjacent nesting areas, are key components of sage grouse habitat. Sage grouse leks range in size from 0.4 to 40 ha (Fish and Wildlife Service 2010) and are typically found in areas of open sagebrush in predominantly flat topography (Connelly et al. 2004). To estimate (via the Monte Carlo approach) the number of sage grouse leks that could potentially be lost due to petroleum development, necessary input data include mapped lek locations and the quantified relationship between petroleum development and lek abandonment. Details of the petroleum development impact on 
sage grouse leks are the subject of on-going research (e.g., Lyon 2000; Holloran 2005; Walker et al. 2007); for the purpose of this example, we assume leks within $3.2 \mathrm{~km}$ of a well location will be abandoned, following Walker et al. (2007). Similar to PJ woodland, a more comprehensive study could include roads and other infrastructure, the impacts of which would be calculated in much the same way as well pads.

The proposed Monte Carlo algorithm provides a robust approach to combine the input PDFs. Each Monte Carlo iteration (Fig. 4) begins with the drawing of one value from the PDF of the number of cells that contain petroleum resource, followed by the distribution of the resource across the AU at random or using relevant (but inherently speculative) constraining information from the petroleum assessment report (Johnson and Roberts 2003). The algorithm then assigns well pads to each petroleumcontaining cell according to whatever constraints are provided for this step. The simplest approach is to do this randomly, but more accurate approaches would follow local or standard development practices to constrain the locations of the pads, such as avoiding steeply sloping terrain and restricted areas. We would then calculate the area of PJ woodland and the number of sage grouse leks impacted by the simulated development infrastructure and sum these quantities across the AU or other areas of interest to determine one possible scenario for PJ woodland and habitat loss. By running tens of thousands of Monte Carlo iterations we would build distributions that quantify the possible PJ woodland and lek loss associated with petroleum resource development, including assessment of any cumulative effects such as habitat fragmentation. The final output of the impact assessment would be two PDFs: one showing the area of PJ woodland lost and one showing the number of sage grouse leks impacted by petroleum extraction. A possible secondary product would be maps showing probabilities of particular woodland and lek areas being impacted, based on compilation of the individual simulation maps. Such maps would be of value primarily if the assignment of petroleum resource across the AU can be constrained by valid auxiliary information and/or if the siting of well pads and infrastructure within each petroleum-bearing cell is guided by realistic modeling.

The variations and extensions to this impact assessment are limited only by data availability. For example, we could quantify job creation or other local or national economic benefits of gas development (e.g., Gunther 1992). We could quantify water requirements for hydraulic fracturing associated with gas production, or (with appropriate data) possible water quality impacts. To the extent that it can be quantified, we could assess the national security benefits associated with producing Piceance Basin gas relative to importing gas. Alternatively, we could compare development alternatives by quantifying the petroleum unavailable for production under a conservation strategy that protects areas for PJ woodland or sage grouse leks. In this case, the simulation would include restrictions on the placement of wells in critical habitat or other protected areas and we would calculate output distributions that describe how much petroleum would be available for extraction, and how much would be unavailable for extraction, if particular restrictions were in place. Finally, the study could be carried through to monetary valuation and a cost-benefit analysis could be used to evaluate trade-offs between habitat conservation and petroleum production. To the extent that these more complex analyses require customized, site-specific approaches, new data acquisition, and extensive stakeholder involvement, such work would constitute Level 3 studies.

\section{Minerals, Lynx, and Water Quality in Southwestern Colorado}

The San Juan volcanic field in southwestern Colorado has long been an area of mining activity due to its rich mineral endowment (Fig. 3). The USGS completed assessments for several types of mineral deposits in this area in 1996. We focus on the epithermal vein deposits of the quartz-adularia type, identified as PT CR26 in southwestern Colorado (US Geological Survey National Mineral Resource Assessment Team 2002; Fig. 5). These deposits contain gold, copper, silver, and other metals. The US Geological Survey National Mineral Resource Assessment Team (2002) estimated that CR26 has a $90 \%$ chance of containing one or more undiscovered ore deposits, a $50 \%$ chance of containing three or more, a $10 \%$ chance of containing five or more, a $5 \%$ chance of containing seven or more, and a $1 \%$ chance of containing ten or more deposits.

Reintroduction of lynx in Colorado between 1999 and 2006 has led to a modest lynx population with a range that partially coincides with the areal distribution of CR26 (Devineau et al. 2010; 


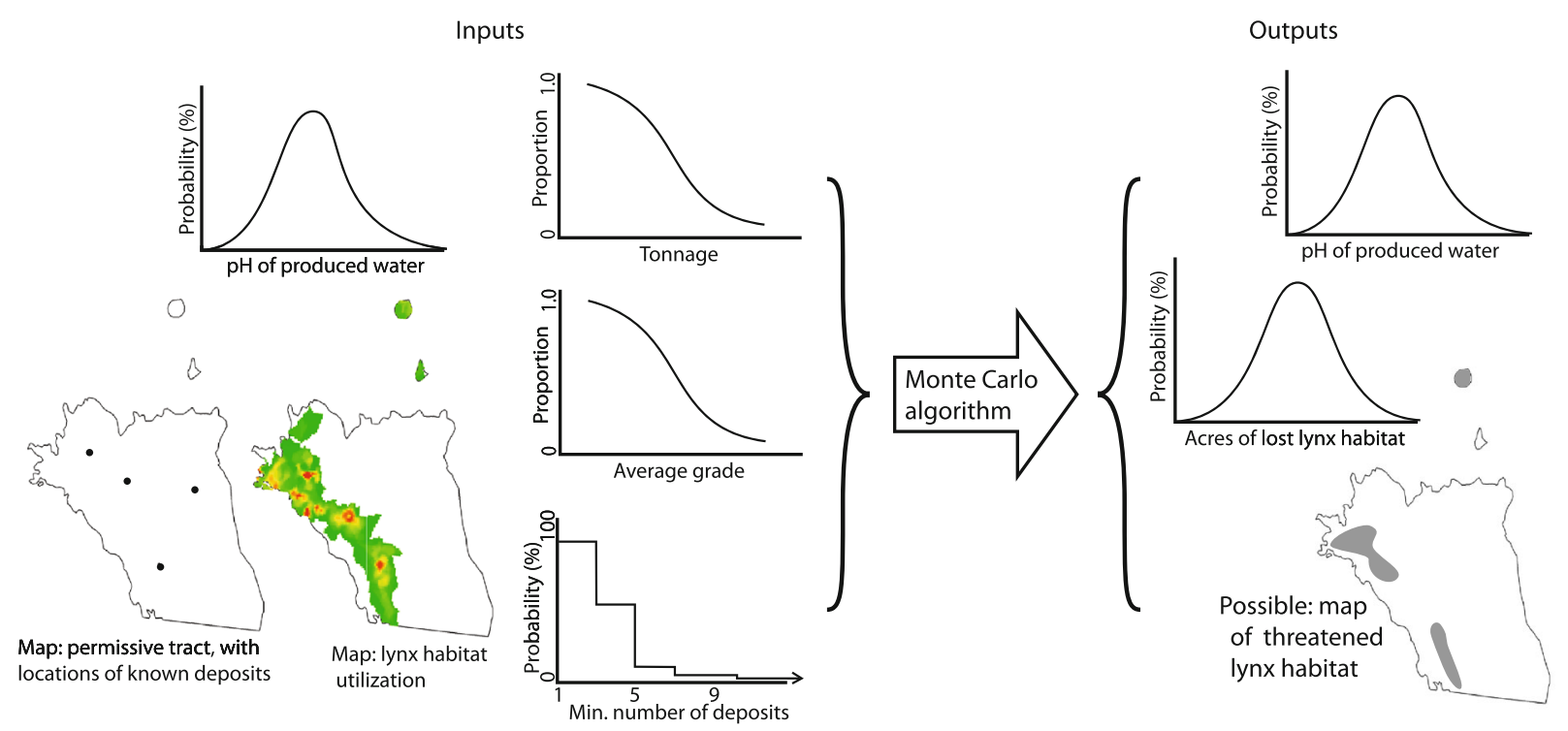

Figure 5. Inputs and outputs for the San Juan minerals conceptual example. The assessment incorporates relevant inputs for existing USGS assessment of minerals in tract CR26, along with maps of Canada lynx habitat and the locations of known quartz-adularia epithermal vein deposits, as well as the probability distribution function for water $\mathrm{pH}$ associated with this deposit type, to determine ranges of possible lost lynx habitat and of possible mine-related water $\mathrm{pH}$.

Theobald and Shenk 2011). Quantifying potential lynx habitat loss associated with development of undiscovered mineral deposits requires a map of lynx habitat (Fig. 5) and a quantitative relationship between mining development and habitat impact. For this example, we assume that any lynx habitat within the surface footprint of a mine is lost.

Water chemistry information is foundational to many water- and species-related concerns in mining areas. Using statistics drawn from compilations of mine-related water data such as those provided by Plumlee et al. (1999), we can generate PDFs that link applicable water quality metrics with deposit type, following Walton-Day et al. (2012). For our assessment of CR26, we would create a PDF describing the $\mathrm{pH}$ of water associated with epithermal vein deposits of quartz-adularia type and use this PDF to predict water $\mathrm{pH}$ associated with each deposit simulated in each Monte Carlo iteration (indicative of groundwater within the deposit area and water produced during mining). This information could be used by engineers planning mine operations, or regionally by land managers studying the possible wildlife impacts in the event that minerelated water enters the ecosystem.

Each Monte Carlo iteration (Fig. 5) begins with the drawing of a value from the PDF for the number of undiscovered mineral deposits in the PT, along with values from the appropriate grade and tonnage PDFs to determine the metal content and sizes of the undiscovered deposits. These deposits could be filtered with an economic algorithm (e.g., Robinson and Menzie 2012) if desired. The algorithm would then distribute these deposits across the PT to simulate their spatial locations, either randomly or using any relevant geologic constraints. For each of these simulated deposits, we would calculate the area of disturbed lynx habitat and we would draw a value from the PDF of water $\mathrm{pH}$, incorporating any local geologic information that might constrain the $\mathrm{pH}$ range. Repeating this process for tens of thousands of Monte Carlo iterations would span the range of possibilities, and provide PDFs of the final outputs: area of lynx habitat potentially lost, and likely $\mathrm{pH}$ for mining waters. Relevant location-specific information would be available if spatial aspects of the individual Monte Carlo simulations are constrained by geologic and/or infrastructure-related (e.g., topographic constraints on road placement) information. Depending on specific study goals, the $\mathrm{pH}$ results might be presented as a likelihood that mine water $\mathrm{pH}$ in any given location would be lower than 6.5, which is an important threshold for aquatic life (US Environmental Protection Agency 1976) and thus a valuable piece of information for mine planning. 
As with the Piceance Basin example, possible extensions and modifications of this study are limited only by available data. For example, benefits of copper availability for manufacturers and to the national or global economy could be quantified. As another example, the assessment of water $\mathrm{pH}$ could be expanded to quantify potential impacts on aquatic life, or other impacts of interest, though this would require assumptions regarding the mine engineering and remediation. Such quantification would also likely requires estimates of the volume of water resulting from, or interacting with, mining operations; these estimates would contain considerable uncertainty due to the range of conditions that could exist at any given site. The assessment could also be extended to include cost-benefit analysis to compare various development or protection schemes, provided that the value of relevant ecosystems services can be adequately quantified. Inclusion of these more complicated aspects could necessitate new data collection and customized, sitespecific analysis approaches and as such would lead to Level 3 classification.

\section{DISCUSSION AND CONCLUSIONS}

Our proposed assessment framework is intended to provide a cohesive scientific foundation on which to base resource management decisions for a broad range of users in a wide range of contexts. The framework is unique in that it provides a systematic, quantitative link between assessments of undiscovered energy and mineral resources and models for the possible impacts of development. The framework represents a robust and reproducible approach for combining the extensive datasets and studies that exist in varied disciplines (e.g., geology, ecology, hydrology, and the social sciences). In addition, the framework provides probabilistic, quantitative estimates of the interrelations between these varied components of the natural world based on established methods for quantitative assessment of energy and mineral resources. Finally, it is applicable to a broad spectrum of questions regardless of scale, scope, or complexity, including the quantitative comparison of various alternative development strategies.

The examples described here illustrate two relatively straightforward applications of the assessment framework. The complexity of possible applications is limited only by the availability of necessary data and quantified relationships between development and impacts. Inclusion of social values (e.g., disrupted viewsheds, lost recreational opportunities, lifestyle improvement due to local economic growth) can readily be accomplished given adequate data (e.g., Sherrouse et al. 2011; Bagstad et al. 2012). Inclusion of economic components and extension to full economic valuation are possible for any application, given adequate data and suitable valuation schemes; methods and data related to ecosystems services provide a means for mapping and valuing natural processes that benefit humans. Further-reaching effects of resource development and use (e.g., National Research Council 2009; Graedel and van der Voet 2010) can be readily included, and relevant information is increasingly becoming available in the form of life-cycle analysis for various resources and commercial products. Given sufficient input data, our approach can incorporate full life-cycle analysis of any desired resource. Contributions to climate change can be quantified much like any other impact (e.g., $\mathrm{CO}_{2}$ created from combustion of petroleum resources), and development impacts (e.g., habitat loss, water consumption) can be calculated relative to projected future global conditions if desired. Similarly, other dynamic aspects can be included as well (e.g., habitat change due to expansion of urban areas).

A more complicated extension of the approach is the inclusion of low-probability, high-consequence events such as a mine tailings dam failure or a petroleum well blowout. These can be quantified with our approach, but they present additional challenges. Quantifying the likelihood and the impact of such an event is difficult due to the inherent dependence on specific site conditions and engineering choices and it would be critical that all assumptions be acceptable to a diverse group of stakeholders. Such studies will likely require Level-3-type analysis (customized to the specific question), at least until standardized approaches can be determined.

Another challenging extension of the approach is the inclusion of impacts that are linked to the rate of energy or mineral resource development. For example, the simultaneous mining of a number of mineral deposits or drilling of a number of petroleum wells in a particular area might result in unrecoverable habitat loss, whereas sequential development of the same resources over a longer period could allow for progressive disturbance, restoration, and recovery at each mine or well site and thus significantly reduce long-term impact. Quantifying this relationship would require time-dependent 
input data, but the end result would potentially be highly valuable to land managers as pre-development modeling and planning could lead to an optimized tradeoff between habitat preservation and energy or mineral resource availability. Including economic components in such work is possible and potentially quite valuable (changing commodity prices play a key role in resource development, and different resource production rates can impact development economics); this would require timedependent economic valuation.

The presented conceptual examples represent two cases where the necessary data and quantified impact relationships exist, and thus where implementation of this assessment framework can be achieved in the near future. Additional examples exist, but a key challenge to widespread use of this approach will be the determination of standardized data types and development impact relationships for problems of interest. A critical feature of our approach is the handling of data uncertainty, but to accomplish this the uncertainty in the input data must be accurately characterized. Broad input uncertainty will simply result in broad output uncertainty. We envision that the widespread implementation of this algorithm will begin with the studies that can be conducted immediately and for which the output uncertainty is acceptable to the problem being considered. In cases where final uncertainty is greater than what is acceptable for stakeholders and/or for policy requirements, new data acquisition or analysis will be required to minimize uncertainty in the particular aspects of input data that require improvement. For undiscovered energy or mineral deposits the data are most often acquired by private industry, whereas for water and ecological aspects the data may be acquired by private, governmental, or academic researchers.

The described assessment framework (including the Monte Carlo approach and the three-level terminology) is intended to provide results that are helpful to a range of users, and that can be readily communicated to these users. The statistical nuances of the methodology do not always need to be communicated, but the significance of the output PDFs must be communicated to users of the data. A common way to convey the uncertainty represented by the PDFs is to present just a few key values such as the quantities that correspond with 5, 50, and 95\% likelihood. Another key aspect of the approach that must be communicated clearly is the set of assumptions that underlie the assessment methodology; all incorpo- rated data, weighting schemes, and quantified impact relationships must be clearly stated in order for the work to maintain the necessary transparency.

No one can predict the future, but our framework can probabilistically quantify the possible future impacts (positive and negative) of energy and mineral development based on the quantity of energy/mineral resource thought to be present in a given area. Though it will not answer all possible questions, the provided information is intended to be accurate, standardized, and objective, such that it can be used and understood by diverse stakeholders including land managers, private companies, non-profit organizations, and policy makers. The information is intended to be valuable in many decision-making contexts, including any scale of land-use decision-making, resource availability versus environmental degradation concerns, and a suite of economic analyses.

\section{ACKNOWLEDGMENTS}

This study was supported by the John Wesley Powell Center for Analysis and Synthesis, funded by the U.S. Geological Survey. We very much appreciate the opportunity to assemble this diverse group and tackle this challenging multi-disciplinary problem in the setting of the Powell Center, and we are grateful to Jill Baron, Marty Goldhaber, Lorie Hughes, and the many others who helped make this possible. We are grateful to Natasha Carr, Zack Bowen, and Ron Charpentier for their contributions to various aspects of this project. We thank Meryl Marshall-Daniels for her assistance. And we thank Jill Baron (USGS) and two anonymous journal reviewers who have helped to improve this manuscript.

OPEN ACCESS This article is distributed under the terms of the Creative Commons Attribution License which permits any use, distribution, and reproduction in any medium, provided the original author(s) and the source are credited.

\section{REFERENCES}

Allen, L. A., \& Kauffman, M. J. (2012). WLCI researchers employ new approaches to help managers conserve deer migrations: 
WLCI Fact Sheet 2, US Geological Survey. Retrieved February 22, 2013, from http://pubs.usgs.gov/wlci/fs/2/.

American Association of Petroleum Geologists (AAPG) Committee on Resource Evaluation. (1999). Subcommittee to Review the United States Onshore Continuous (Unconventional) Gas Assessment Methodology Used by the USGS. Retrieved May 8, 2013, from http://certmapper.cr.usgs.gov/ data/noga00/natl/text/core_report.pdf.

Bagstad, K. J., Semmens, D., Winthrop, R., Jaworski, D., \& Larson, J. (2012). Ecosystem services valuation to support decision making on public lands-A case study of the San Pedro River watershed, Arizona. US Geological Survey Scientific Investigations Report 2012-5251. Retrieved February 22, 2013, from http://pubs.usgs.gov/sir/2012/5251/sir2012-5251.pdf.

Champ, P. A., Boyle, K. J., \& Brown, T. C. (2003). A primer on nonmarket valuation. Dordrecht: Kluwer, $592 \mathrm{p}$.

Charpentier, R. R., \& Cook, T. A. (2010). Improved USGS methodology for assessing continuous petroleum resources. US Geological Survey Data Series 547. Retrieved February 22, 2013, from http://pubs.usgs.gov/ds/547/downloads/DS547v2.pdf.

Colorado Division of Wildlife. (2006). Colorado's comprehensive wildlife conservation strategy and wildlife action plans. State of Colorado. Retrieved February 22, 2013, from http://wild life.state.co.us/SiteCollectionDocuments/DOW/WildlifeSpecies/ CWCS_FinalReport2006.pdf.

Connelly, J. W., Knick, S. T., Schroeder, M. A., \& Stiver, S. J. (2004). Conservation assessment of greater sage-grouse and sagebrush habitats. Western Association of Fish and Wildlife Agencies. Retrieved February 22, 2013, from http://www.sage brushsea.org/WAFWA_page.htm.

Copeland, H. E., Doherty, K. E., Naugle, D. E., Pocewicz, A., \& Kiesecker, J. M. (2009). Mapping oil and gas development potential in the US intermountain west and estimating impacts to species. PLOS ONE. doi:10.1371/journal.pone.0007400.

Crovelli, R. A. (2005). Analytic resource assessment method for continuous petroleum accumulations-The ACCESS assessment method. In US Geological Survey Southwestern Wyoming Assessment Team, Petroleum systems and geologic assessment of oil and gas in the southwestern Wyoming province, Wyoming, Colorado, and Utah. US Geological Survey Digital Data Series DDS-69-D. Retrieved February 22, 2013, from http://certmap per.cr.usgs.gov/data/noga00/natl/text/CH_22.pdf.

Devineau, O., Shenk, T. M., White, G. C., Doherty, P. F., Lukacs, P. M., \& Kahn, R. H. (2010). Evaluating the Canada lynx reintroduction programme in Colorado: Patterns in mortality. Journal of Applied Ecology, 47(3), 524-531.

Dunford, R. W., Ginn, T. C., \& Desvousges, W. H. (2004). The use of habitat equivalency analysis in natural resource damage assessments. Ecological Economics, 48(1), 49-70.

Farber, S., Costanza, R., Childers, D. L., Erickson, J., Gross, K., Grove, M., et al. (2006). Linking ecology and economics for ecosystem management. BioScience, 56(2), 117-129.

Fargione J., Kiesecker J., Slaats M. J., \& Olimb, S. (2012). Wind and wildlife in the Northern Great Plains: Identifying lowimpact areas for wind development. PLoS ONE, 7(7). doi: 10.1371/journal.pone.0041468.

Fish and Wildlife Service. (2010). Endangered and threatened wildlife and plants; 12-Month findings for petitions to list the greater sage grouse (Centrocercus urophasianus) as threatened or endangered. Federal Register 50 CFR 17. March 4, 2010.

Graedel, T. E., \& van der Voet, E. (2010). Linkages of sustainability. Cambridge, MA: MIT Press, $532 \mathrm{p}$.

Gunther, T. M. (1992). Quantitative assessment of future development of copper/silver resources in the Kootenai National Forest, Idaho/Montana: Part II-Economic and policy analysis. Nonrenewable Resources, 1(4), 267-280.

Hawkins, S., Cook, T., Haines, S., \& Diffendorfer, J. (2012). A probabilistic approach to estimates of future oil and gas development impacts. Wyoming Landscape Conservation Initiative Science Workshop Proceedings, Wyoming Landscape Conservation Initiative. Retrieved February 22, 2013, from https://my.usgs.gov/confluence/download/attachments/ 318144721/WLCISciWshop2012_Abstracts \%20Final4.refor matted.pdf?api=v2.

Holloran, M. J. (2005). Greater sage-grouse (Centrocercus urophasianus) population response to natural gas field development in Western Wyoming. Doctoral dissertation. Department of Zoology and Physiology, University of Wyoming. Laramie.

Hufschmidt, M. M., James, D. E., Meister, A. D., Bower, B. T., \& Dixon, J. A. (1983). Environment, natural systems, and development: An economic valuation guide. Baltimore: Johns Hopkins University Press.

International Atomic Energy Agency. (2005). Energy indicators for sustainable development: Guidelines and methodologies. Vienna: International Atomic Energy Agency.

Johnson, R. C., \& Roberts, S. B. (2003). The Mesaverde total petroleum system, Uinta Piceance province, Utah and Colorado, in USGS Uinta-Piceance assessment team, petroleum systems and geologic assessment of oil and gas in the UintaPiceance Province, Utah and Colorado. US Geological Survey Digital Data Series DDS-69-B. Retrieved May 8, 2013, from http://pubs.usgs.gov/dds/dds-069/dds-069-b/REPORTS/ Chapter_7.pdf.

Latysh, N., \& Bristol, S. (2011). Wyoming landscape conservation initiative data management and integration: WLCI fact sheet 1 . US Geological Survey. Retrieved May 8, 2013, from http:// pubs.usgs.gov/wlci/fs/1/.

Lyon, A. G. (2000). The potential effects of natural gas development on sage-grouse near Pinedale, Wyoming. Masters thesis. Department of Zoology and Physiology. University of Wyoming, Laramie.

Mihalasky, M. J., Peters, S. G., Carter, J., Dillingham, W. S., Dobbin, J., Hammarstrom, J. M., Lampietti, F. M. J., Mack, T. J., Sutphin, D. M., Verstraeten I. M., \& Mihalasky, F. I. (2006). Dynamic mineral resources management, Anosy, Madagascar-Anosy region dynamic spatial analysis GIS, identification of three areas having future mineral potential, and summary of socioeconomic planning (Version 1.1e). Washington, DC: The World Bank, Division of Oil, Gas, Mining Policy Division, Department of Oil, Gas, Mining and Chemicals.

Mulder, K., \& Hagens, J. N. (2008). Energy return on investment: Toward a consistent framework. Ambio, 37(2), 74-79.

National Research Council. (2009). Hidden costs of energy: Unpriced consequences of energy production and use. Washington, DC: National Academies Press.

Nicot, J. P., \& Scalon, B. (2012). Water use for shale-gas production in Texas, US. Environmental Science and Technology, 46(6), 3580-3586.

Noble, B. (2008). Strategic approaches to regional cumulative effects assessment: A case study of the Great Sand Hills, Canada. Impact Assessment and Project Appraisal, 26(2), 78-90.

Okey, B. W., \& Kuzemchak, M. J. (2009). Modeling potential wildlife-wind energy conflict areas, Center for Rural Pennsylvania. Retrieved February 22, 2013, from http://www.rural. palegislature.us/documents/reports/wind_wildlife_report09.pdf.

Plumlee, G. S., Smith, K. S., Montour, M. R., Ficklin, W. H., \& Mosier, E. L. (1999). Geologic controls on the composition of natural waters and mine waters draining diverse mineraldeposit types. In L. H. Filipek \& G. S. Plumlee (Eds.), The environmental geochemistry of mineral deposits, Part B. Case studies and research topics (pp. 373-432). Reviews in Economic Geology: Society of Economic Geologists.

Randall, J. M., Parker, S. S., Moore, J., Cohen, B., Crane, L., Christian, B., Cameron, D., MacKenzie, J., Klausmeyer, K., \& Morrison, S. (2010). Mojave desert ecoregional assessment. The nature conservancy. Retrieved February 22, 2013, from 
http://conserveonline.org/workspaces/mojave/documents/moj ave-desert-ecoregional-2010/@@view.html.

Robinson, G. R., \& Menzie, W. D. (2012). Economic filters for evaluating porphyry copper deposit resource assessments using grade-tonnage deposit models, with examples from the US Geological Survey global mineral resource assessment. US Geological Survey Scientific Investigations Report 20105090-H. Retrieved April 10, 2013, from http://pubs.usgs.gov/ $\operatorname{sir} / 2010 / 5090 / \mathrm{h} /$.

Root, D. H., Menzie, W. D., \& Scott, W. A. (1992). Computer Monte Carlo simulation in quantitative mineral resource estimation. Natural Resources Research, 1(2), 125-138.

Schmoker, J. W. (2005). US Geological Survey assessment concepts for continuous petroleum accumulations. In US Geological Survey Southwestern Wyoming Assessment Team, Petroleum systems and geologic assessment of oil and gas in the southwestern Wyoming province, Wyoming, Colorado, and Utah. US Geological Survey Digital Data Series DDS69-D. Retrieved February 22, 2013, from http://certmapper. cr.usgs.gov/data/noga00/natl/text/CH_13.pdf.

Sherrouse, B. C., Clement, J. M., \& Semmens, D. J. (2011). A GIS application for assessing, mapping, and quantifying the social values of ecosystem services. Applied Geography, 31(2), 748-760.

Singer, D. A. (1993). Basic concepts in three-part quantitative assessments of undiscovered mineral resources. Nonrenewable Resources, 2(2), 69-81.

Singer, D. A., \& Menzie, W. D. (2010). Quantitative mineral resource assessments: An integrated approach. Oxford: Oxford University Press.

Snyder, B., \& Kaiser, M. J. (2009). Ecological and economic costbenefit analysis of offshore wind energy. Renewable Energy, $34,1567-1578$

Spanski, G. T. (1992). Quantitative assessment of future development of copper/silver resources in the Kootenai National Forest, Idaho/Montana: Part I-estimation of the copper and silver endowments. Nonrenewable Resources, 1(4), 163-183.
Theobald, D. M., \& Shenk, T. M. (2011). Areas of high habitat use from 1999-2010 for radio-collared Canada lynx reintroduced to Colorado. Colorado State University. Retrieved February 22, 2013, from http://wildlife.state.co.us/SiteCollectionDocu ments/DOW/Research/Mammals/Publications/LynxHabitat UseMapReport.pdf.

Thórhallsdóttir, T. E. (2007). Environment and energy in Iceland: A comparative analysis of values and impacts. Environmental Impact Assessment Review, 27(6), 522-544.

Unsworth, R. E., \& Bishop, R. C. (1994). Assessing natural resource damages using environmental annuities. Ecological Economics, 11(1), 35-41.

US Environmental Protection Agency. (1976). Quality criteria for water. US Environmental Protection Agency. Retrieved February 22, 2013, from http://water.epa.gov/scitech/swguid ance/standards/criteria/current/upload/2009_01_13_criteria_ redbook.pdf.

US Geological Survey National Mineral Resource Assessment Team. (2002). Assessment of undiscovered deposits of gold, silver, copper, lead, and zinc in the United States. US Geological Survey Open File Report 02-198. Retrieved May 8, 2013, from http://pubs.usgs.gov/of/2002/of02-198/1_NATIONAL_ASSE SSMENT.PDF.

Walker, B. L., Naugle, D. E., \& Doherty, K. E. (2007). Greater sage-grouse population response to energy development and habitat loss. Journal of Wildlife Management, 71(8), 26442654.

Walton-Day, K., Balistrieri, L. S., Berger, B. R., Johnson, K. M., Haines, S. S., \& Diffendorfer, J. E. (2012). Integrated resource assessments-A framework to consider the potential consequences of mineral resource development. In Proceedings of US Environmental Protection Agency Hard Rock Mining Conference.

Zafonte, M., \& Hampton, S. (2007). Exploring welfare implications of resource equivalency analysis in natural resource damage assessments. Ecological Economics, 61(1), 134-145. 